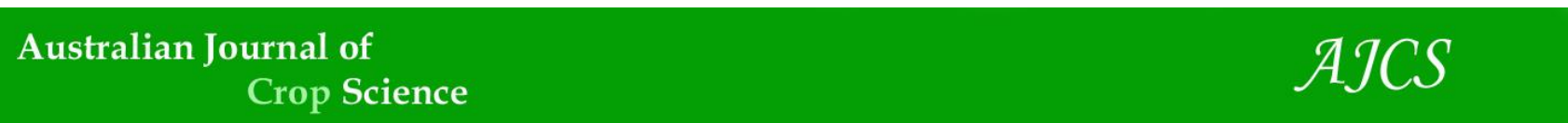

AJCS 15(05):764-772 (2021)

ISSN:1835-2707

doi: $10.21475 /$ ajcs.21.15.05.p3192

\title{
Hop (Humulus lupulus L.) phenology, growth, and yield under subtropical climatic conditions: Effects of cultivars and crop management
}

\author{
Aleyda Acosta-Rangel ${ }^{1}$, Jack Rechcigl ${ }^{1}$, Simon Bollin ${ }^{2}$, Zhanao Deng ${ }^{1}$, and Shinsuke Agehara ${ }^{{ }^{*}}$ \\ ${ }^{1}$ University of Florida, Institute of Food and Agricultural Sciences, Gulf Coast Research and Education Center. \\ Wimauma, FL 33598, US. \\ ${ }^{2}$ Hillsborough County Florida, Economic Development Department, Agriculture Industry Development. Tampa, FL \\ 33602, US.
}

*Corresponding author: sagehara@ufl.edu

\begin{abstract}
Commercial hop (Humulus lupulus L.) production occurs predominantly in temperate climates. The objectives of this study were to characterize the phenology of hops under subtropical climatic conditions and to determine the growth and yield potential. Two field experiments were conducted in Florida, southeastern United States. Rhizomes were planted in April. Data were collected during the establishment year. In the first experiment, we evaluated 7 American, 5 European, and 1 Japanese cultivars in a randomized complete block design. Bine height, main bine number, lateral shoot number, and dry cone yield (10\% moisture) were recorded. Yield varied considerably, ranging from 0 to $197 \mathrm{~kg} \mathrm{ha}^{-1}$. The top three yielding cultivars were 'Cascade', 'CTZ', and 'Nugget', all of which were American cultivars. Yield had positive correlations with main bine number and lateral shoot number, but it had no significant correlation with bine height. In the second experiment, we determined the duration of each phenological stage in 'Cascade'. Reproductive phenology was characterized by premature and nonsynchronous flowering. Prolonged flowering resulted in multiple harvests over 61 days, starting in mid-June. We also evaluated crop management treatments, which consisted of three levels of hill spacing $(76,91$, and $107 \mathrm{~cm})$ and two nitrogen $(\mathrm{N})$ rates $\left(109\right.$ and $\left.130 \mathrm{~kg} \mathrm{ha}^{-1}\right)$ in a factorial combination. Treatments were arranged in a split-plot design with hill spacing as the main-plot factor. Yield on a per-area basis increased with reducing hill spacing and increasing $\mathrm{N}$ rate by $41 \%$ and $38 \%$, respectively. Our results demonstrate unique reproductive phenology of hops under subtropical climatic conditions, which prevents once-overharvest but enables the off-season supply of fresh hops over an extended period. This study provides a benchmark to develop production strategies for hops suitable to subtropical climates.
\end{abstract}

Keywords: acclimation, day length, fertilization, nutrient management, nitrogen, plant spacing, photoperiod.

Abbreviations: DAP_days after planting; FAWN_Florida Automated Weather Network; IHGC_International Hop Growers' Convention; UAN_urea and ammonium nitrate.

\section{Introduction}

Hops (Humulus lupulus L.) are a dioecious perennial crop that belongs to the Cannabaceae family. Female flowers develop into cones or strobiles, which are an essential ingredient in brewing that adds bitterness and aroma to beer. Driven by the recent craft beer movement, hop production increased dramatically across the world over the last 10 years (Brewers Association, 2020). The United States (US) is the world's largest hop producer, with 56,021 tons of hops produced on 22,883 hectares and an annual farm gate value of US\$637 million in 2019 (IHGC, 2020; USDA-NASS, 2019). From 2012 to 2019, the US hop production volume and acreage increased by $45 \%$ (IHGC, 2020). In 2018, craft beer sales accounted for more than $25 \%$ of the US\$116 billion US beer market (Brewers Association, 2020). Hops are produced predominantly in temperate areas at latitudes between $35^{\circ}$ and $55^{\circ}$ north and south of the equator (DeNoma, 2000). Although hop production is currently expanding into non-traditional cultivation areas (Hop
Growers of America, 2019), commercial hop production in the subtropics is almost nonexistent (IHGC, 2020; USDANASS, 2019). Development of hops as an alternative crop can provide new economic and market opportunities to both growers and craft breweries in this climatic zone.

All hop cultivars share a common ancestor from Europe (Boutain, 2014; Jakse et al., 2004; Murakami et al., 2006), but most American cultivars are hybrids between European cultivars and wild hops in the US (Jakse et al., 2004; Neve, 1991). There are more than 160 hop cultivars in the world (USDA-ARS, 2007), and for agronomic purposes, hop cultivars have been classified into two landraces: American or European hops. American landrace cultivars tend to have high yields per plant, vigorous plant growth, and high adaptive capacity to various soil types and $\mathrm{pH}$ levels, whereas European landrace cultivars (British and Continental Europe types) are smaller plants, with lower 
yields per plant and relatively low adaptive capacity to different growing conditions (Kemme, 2013).

Regardless of landraces and cultivars, hops are classified as short-day plants because they flower when day length becomes shorter than a specific number of daylight hours, referred to as critical day length. In general, the critical day length for hops is 15 to 16 hours (Krebs, 2019; Neve, 1991; Thomas and Schwabe, 1969). Flowering is an important phenological event for hops, as its timing, rate, and uniformity determine the potential crop yield and quality (De Keukeleire et al., 2003). Hop plants are most productive when adequate vegetative bine growth is achieved before flowering is induced. Day length is a function of latitude, and the latitude range generally accepted for commercial hop production is $35^{\circ}$ to $55^{\circ}$ north or south of the equator (Dodds, 2017). For example, two leading hop production regions in the world, Hallertau in Germany and Yakima in the US, are located at $48.6^{\circ} \mathrm{N}$ and $46.6^{\circ} \mathrm{N}$, respectively. The subtropics are typically located in latitudes between $23.5^{\circ}$ and $35^{\circ}$ north or south of the equator, where day length is always below the critical day length for hops (e.g., $<14$ hours in Florida, US). In this climatic zone, therefore, phenology is an important cultivar selection criterion. Characterization of phenology can also provide a foundation for developing crop management and marketing strategies.

The objectives of this study were to identify suitable cultivars and important yield-determining traits, characterize phenological behaviors, and determine the effects of crop management practices on hops grown under subtropical climatic conditions.

\section{Results}

\section{Yields of 13 hop cultivars}

Figure 2 shows dry cone yields of 13 tested cultivars. There was a broad range of yield variation among the hop cultivars. 'Cascade' had the highest yield (197 kg ha-1), followed by 'CTZ' (121 kg ha-1) and 'Nugget' (93 kg ha-1). A low-yielding group consisting of five cultivars, 'Chinook', 'Centennial', 'Willamette', 'Saaz', and 'Magnum', produced 15-50 kg ha ${ }^{-1}$. 'Crystal' and Fuggle' produced negligible yields of less than $1 \mathrm{~kg} \mathrm{ha}^{-1}$. Three cultivars, 'Perle', 'Tettnanger', and 'Sorachi Ace', did not produce any harvestable cones. These results show a tendency for American landrace cultivars to produce higher yields than European landrace or Japanese cultivars. For example, the three highest yielding cultivars were all American landrace cultivars, which had significantly higher yields than any European landrace cultivar. Two European landrace cultivars ('Perle' and 'Tettnanger') and the Japanese cultivar ('Sorachi Ace') did not produce any cones.

\section{Correlation between yield and growth traits}

Plant growth was highly variable among the 13 tested cultivars: maximum bine height, main bine number per hill, and lateral shoot number per hill ranged $229-412 \mathrm{~cm}, 2-9$, and $2-13$, respectively (Figure 3 ). Dry cone yield was positively correlated with both main bine number $(P<0.01$, $\left.r^{2}=0.645\right)$ and lateral shoot number $\left(P<0.01, r^{2}=0.513\right)$. Yields greater than $150 \mathrm{~kg} \mathrm{ha}^{-1}$ were obtained only for 'Cascade' plots, which had more than 6 main bines and 8 lateral shoots per hill. The linear regression analysis showed that an increment of one main bine or lateral shoot per hill could potentially increase yield by 35 or $19 \mathrm{~kg} \mathrm{ha}^{-1}$, respectively. By contrast, no correlation was found between yield and bine height $(P=0.568)$ despite the broad range of vertical growth exhibited by the cultivars. For example, 'Willamette' grew as much as $412 \mathrm{~cm}$, but its yield was 12 times lower than 'Cascade' (16 kg ha-1 versus $197 \mathrm{~kg} \mathrm{ha}^{-1}$ ), which reached $277 \mathrm{~cm}$ in the cultivar experiment. On average, the maximum bine height for all cultivars was 294 $\mathrm{cm}$, representing $\sim 50 \%$ of the trellis height.

\section{Phenology of 'Cascade' hops}

Figure 4 shows the phenology of 'Cascade' hop plants grown in Florida's subtropical climate from shoot emergence to cone maturity. The growing season, from planting to harvest, lasted 130 days (8 Apr. - 16 Aug. 2016). The rhizomes started producing new shoots 7 DAP (15 Apr.) and continued for 21 more days. The bine elongation stage lasted 52 days (26 Apr. - 17 June), and bines from the same hop plant reached different heights depending on the time of shoot emergence. The first bines started to elongate 18 DAP (26 Apr.), but their growth stopped when they reached $\sim 70 \mathrm{~cm}$ tall, had more than 15 nodes, and inflorescence buds appeared in the upper third section. The shoots that emerged late (end of April and beginning of May) developed bines that reached $300 \mathrm{~cm}$ by the end of the bine elongation stage, and before they started to flower. Although few lateral shoots arose from the growing bines, hop plants did not have a distinguishable stage for lateral shoot formation during the 2016 season. The flowering stage started 33 DAP, was unsynchronized, and lasted for 61 days (11 May - 11 July). For each bine, flowering first occurred in the apical bud and then was moved to the axillary buds. One female spike (inflorescence) emerged from each apical or axillary bud and remained open for $\sim 12$ days before turned into a cone. Therefore, single cones per bud were observed in the main bines during both: cone development and cone maturity stages. These stages started 45 and 69 DAP and lasted 61 days each: 23 May - 23 July for cone development, and 16 June -16 Aug. for cone maturity.

\section{Hill spacing and nitrogen rate effects on bine height growth of 'Cascade' hops}

Bine height of 'Cascade' increased sigmoidally over time with a plateau at $300 \mathrm{~cm}$, which was about the half of the maximum height of the trellis $(580 \mathrm{~cm}$ ) (Figures $5 \mathrm{~A}$ and $5 \mathrm{C}$ ). Before bines reached the maximum height, other developmental processes, including flowering, cone development and cone maturation, occurred simultaneously. Bine height showed rapid linear growth between 28 and 70 DAP, during which time bines grew at a rate of $6.3 \mathrm{~cm}$ per day $\left(y=6.32 x-146.04, r^{2}=0.99, P<\right.$ $0.001)$. Neither hill spacing $(P=0.8021), \mathrm{N}$ rate $(P=0.7476)$, nor their interaction $(P=0.2492)$ had significant effects on bine height growth (Figures. $5 \mathrm{~A}$ and $5 \mathrm{C}$ ). None of the treatments had a significant effect on the number of bines per hill $(P>0.05)$, which had a cumulative average of $9.5 \pm 0.63$ at 109 DAP (data not shown). No visual differences in bines were observed among spacing treatments (Figure $5 \mathrm{~B})$; however, bines grown at $130 \mathrm{~kg} \mathrm{~N} \mathrm{ha}^{-1}$ appeared greener with more lateral branches at the base of the hill, compared to those at $109 \mathrm{~kg} \mathrm{~N} \mathrm{ha}^{-1}$ (Figure 5D).

\section{Hill spacing and nitrogen rate effects on cone yields of 'Cascade' hops}

The effect of hill spacing on dry cone yield differed depending on the units used for comparison. Hops planted with hill spacing of 76, 91, and $107 \mathrm{~cm}$ yielded 38,44 , and 38 g per hill, respectively (Figure 6B), or 109,106 , and $78 \mathrm{~kg} \mathrm{ha}^{-}$ 
1 , respectively (Figure $6 \mathrm{~A}$ ). Yield on a per-hill basis was unaffected by hill spacing (Figure 6B), whereas yield on a per-area basis increased by $41 \%$ with reducing hill spacing from 107 to $76 \mathrm{~cm}(P=0.059)$ (Figure 6A). Moreover, hops grown with 109 and $130 \mathrm{~kg} \mathrm{~N} \mathrm{ha}^{-1}$ produced 81 and $112 \mathrm{~kg}$ $\mathrm{ha}^{-1}$ of dry cones, respectively, showing a $41 \%$ yield increase with increasing $\mathrm{N}$ rate (Figure 7).

\section{Discussion}

Important yield-determining traits of hops in a subtropical climate

Hop yields vary considerably among landraces and cultivars (USDA-NASS, 2019). In the United States, commercial yields are generally highest for American cultivars, followed by European and then Japanese cultivars. This yield variation among the landraces was also observed in this study. 'Cascade' and 'CTZ' have shown success in their adaptation to different soil types and $\mathrm{pH}$ levels, and they have become the most widely grown cultivars (Allen, 2018; Austin, 2012; Darby et al., 2015; Del Moro, 2015; Forward, 2017; McClellan and McWhirt, 2019; Sirrine, 2015). The relatively low genetic diversity of European cultivars, such as 'Tettnanger' and 'Saaz' (Murakami et al., 2006), may explain their poor performance and acclimation to subtropical climatic conditions in this study. Furthermore, correlation analysis revealed that bine number and lateral shoot number are important yield-determining traits, whereas bine height is not a good yield indicator. These relationships between growth traits and yield must be considered when selecting or developing suitable hop cultivars in subtropical climates.

\section{Phenology of 'Cascade' hops in a subtropical climate and its impact on crop management}

Phenological behaviors are important cultivar selection criteria. Understanding phenology also helps develop crop management and marketing strategies. For hops grown in a temperate climate, Lizotte and Sirrine (2020) classified the phenological stages using the $\mathrm{BBCH}$-scale: sprouting, leaf development, elongation of bines, formation of side shoots, inflorescence emergence, flowering, cone development, and maturity of cones. According to this classification, flowering of hops is a short and synchronized event that generally starts about 90 days after sprouting and remains for about 14 days. Subsequent cone development stages occur successively, and the majority of the cones mature at the same time. In this study, phenology of hops grown in a subtropical climate was characterized for the first time. First, flowering was induced at a premature stage, as early as 26 days after sprouting. Second, flowering occurred over a prolonged period, lasting more than three times as long as the typical flowering period in a temperate climate (13 vs. 61 days). Other unique phenological behaviors include the absence of a distinct lateral shoot formation stage, as well as bine senescence that occurred concurrently with the development of new flowers.

Hop plants flower when they meet two conditions. First, they must reach a specific growth stage, which can be determined by the number of nodes (Thomas and Schwabe, 1969). For example, 'Fuggle', 'CC31', and 'New York' acquire the competence to flower when they develop more than 23 , 12, and 20 nodes, respectively (Thomas and Schwabe, 1969). After acquiring the competence to flower, flowering can be induced when day length is shorter than a critical photoperiod, typically 15 to 16 hours (Krebs, 2019; Neve,
1991). The timing of flowering is a major yield determining factor: hop plants are most productive when adequate vegetative bine growth is achieved before flowering is triggered. Day length is a function of latitude, and the latitude range generally accepted for commercial hop production is $35^{\circ}$ to $55^{\circ}$ north or south of the equator (Dodds, 2017). For example, the leading hop producing region in the US is the Yakima Valley in Washington, where the latitude is $46.6^{\circ} \mathrm{N}$, and the longest day length is about 16 hours (National Oceanic and Atmospheric Administration, 2019). In this study, flowering of 'Cascade' plants occurred as soon as their bines developed 15 nodes (data not shown). The latitude of the study site is $27.76^{\circ} \mathrm{N}$, and the maximum day length is about 14 hours. Therefore, premature and asynchronous flowering can be attributed to the inadequate day length in a subtropical climate.

Unsynchronized cone development makes it impractical to harvest mechanically by once-over harvesting. Instead, mature cones need to be harvested manually over a long period, requiring a substantial amount of labor. On the other hand, unsynchronized cone development enables the supply of fresh hops over a long period. Because fresh hops are extremely perishable, they generally need to be used for brewing within 24 hours of picking. They also need to be refrigerated during shipping, making fresh hops a valuable and expensive commodity. In traditional production areas, most hops are harvested in August and September (Hopsteiner, 2016). The fact that hops can be harvested as early as June in subtropics may provide a value-added opportunity for growers.

\section{Hill spacing has minimal effects on the first-season performance of 'Cascade' hops in Florida}

Plant spacing is an important aspect of crop management to prevent plant competition while maximizing productivity, land and resource use efficiency. In general, aboveground growth competes for light to maximize photosynthesis, whereas roots compete for water and nutrients (Kořen, 2007). In this study, plant growth and yield on a per-hill basis did not indicate plant competition as a result of reducing hill spacing. The large unfilled growing space between twines (Figures $5 \mathrm{~B}$ and $5 \mathrm{D}$ ) also suggests that the competition for light was minimal. It appears that plants had adequate growing space because of the limited establishment year growth. Another explanation for the lack of plant competition may be high use efficiency of resources resulting from frequent water (2-3 times a day) and nutrient supply (weekly) via drip irrigation.

In general, common in-row and between-row plant spacing are 1 to $2 \mathrm{~m}$ and 2.1 to $4.2 \mathrm{~m}$, respectively, providing plant densities of 2268 to 4762 hills per hectare (Kořen, 2007). It has been reported that selecting a proper plant density improves hop yield by up to $10 \%$ (Kořen, 2007). In this study, increasing the hill density from 2045 to 2870 hills per hectare by reducing in-row spacing from 107 to $76 \mathrm{~cm}$ increased yield on a per-area basis by $41 \%$, suggesting that a high hill density is beneficial to maximize the yield during the establishment year. However, hop crowns and roots expand over time and increase productivity as the crop reaches the full yield potential, which normally takes $4-5$ years (Sirrine et al., 2015). At this time, plant competition for water, nutrients, and light could become more pronounced and affect yield. Therefore, the optimum hill spacing may change depending on the crop performance in subsequent years. 
Table 1. Country of cultivar release, average yield (2017-2019), area harvested, and production in the United States for the 13 hop cultivars used in this study.

\begin{tabular}{|c|c|c|c|c|}
\hline Cultivar & Country of cultivar release ${ }^{a}$ & Yield $^{b}$ & Area $^{b}$ & Production $^{b}$ \\
\hline & & $\mathrm{kg} \mathrm{ha}^{-1}$ & ha & Tons \\
\hline CTZ & United States & 3121 & 1213 & 3784 \\
\hline Nugget & United States & 2231 & 565 & 1260 \\
\hline Crystal & United States & 2176 & 239 & 520 \\
\hline Chinook & United States & 2044 & 1028 & 2102 \\
\hline Cascade & United States & 1990 & 2527 & 5030 \\
\hline Centennial & United States & 1889 & 1908 & 3605 \\
\hline Willamette & United States & 1741 & 551 & 959 \\
\hline Magnum & Germany & 1679 & 31 & 52 \\
\hline Tettnanger & Germany & 1317 & 45 & 59 \\
\hline Perle & Germany & 1264 & 31 & 39 \\
\hline Fuggle & United Kingdon & 1244 & 28 & 35 \\
\hline Sorachi Ace & Japan & 1167 & 59 & 69 \\
\hline Saaz & Czech Republic & 864 & 57 & 49 \\
\hline
\end{tabular}

aSource: USDA-ARS (2007), bSource: USDA-NASS (2019).

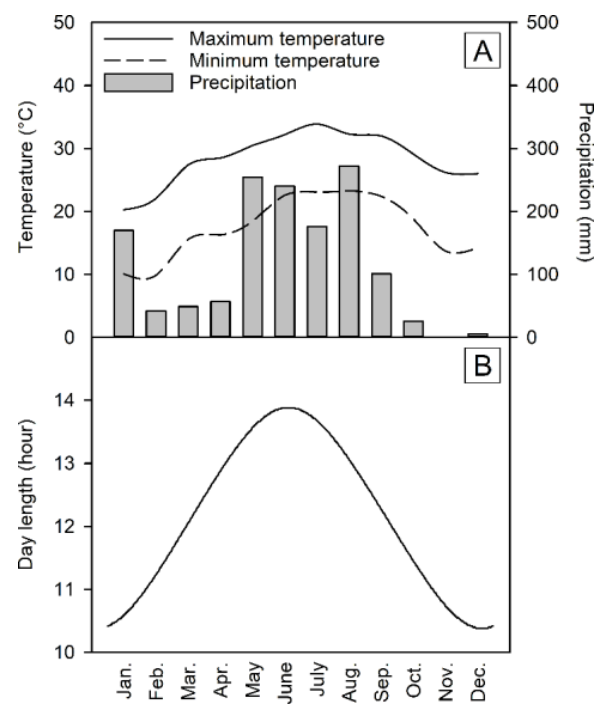

Fig 1. Weather conditions and day length at the experiment site (Balm, Florida, United States) in 2016: (A) Average maximum and minimum temperatures and accumulated precipitation per month, and (B) Day length measured as hours between sunrise and sunset.

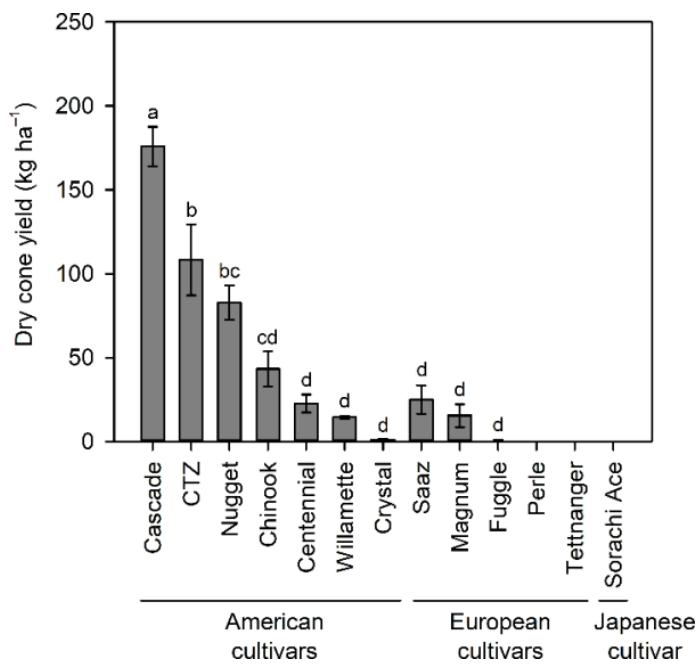

Fig 2. Dry cone yields of 13 hop cultivars grown under subtropical climatic conditions (Balm, Florida, United States). Means $\pm S E(n=$ 3-6) with the same letter are not significantly different (Tukey-Kramer test, $P<0.05$ ). Cultivars that did not produce any cones show no mean separation letter, as they were not included in the statistical analysis. Cultivars are grouped into three landraces as shown below the cultivar names. 


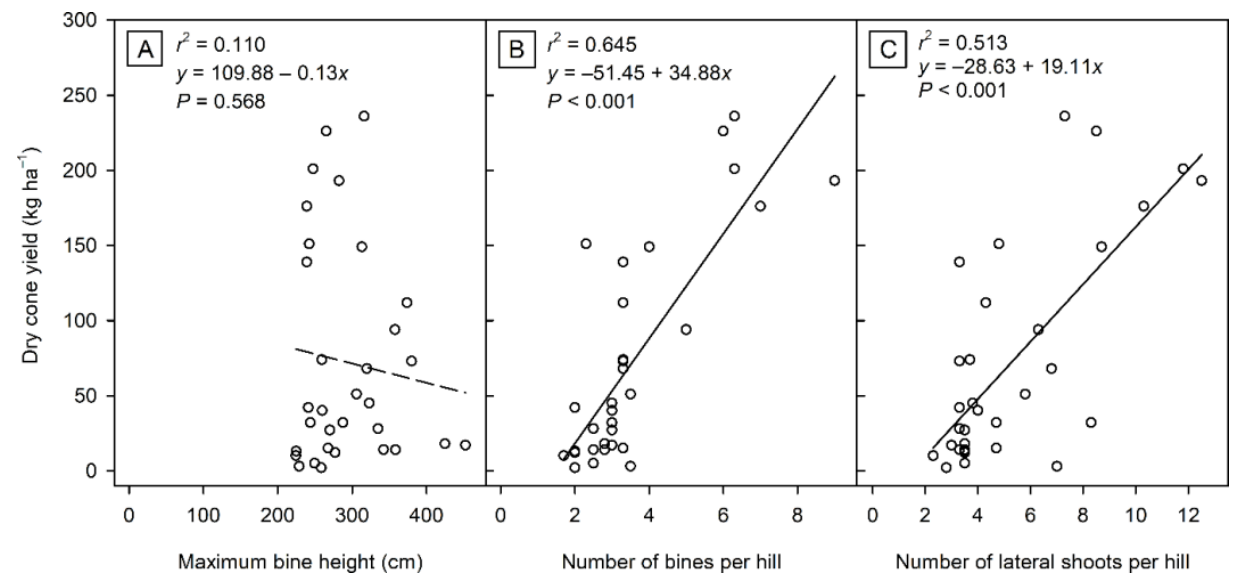

Fig 3. Linear correlations between hop dry cone yield and different growth traits: (A) maximum bine length, (B) number of bines per hill, and (C) number of lateral shoots per hill. Data were collected from 13 hop cultivars grown under subtropical climatic conditions (Balm, Florida, United States). Datapoints $(n=45)$ represent mean values for individual plots (experimental units) for 13 hop cultivars.

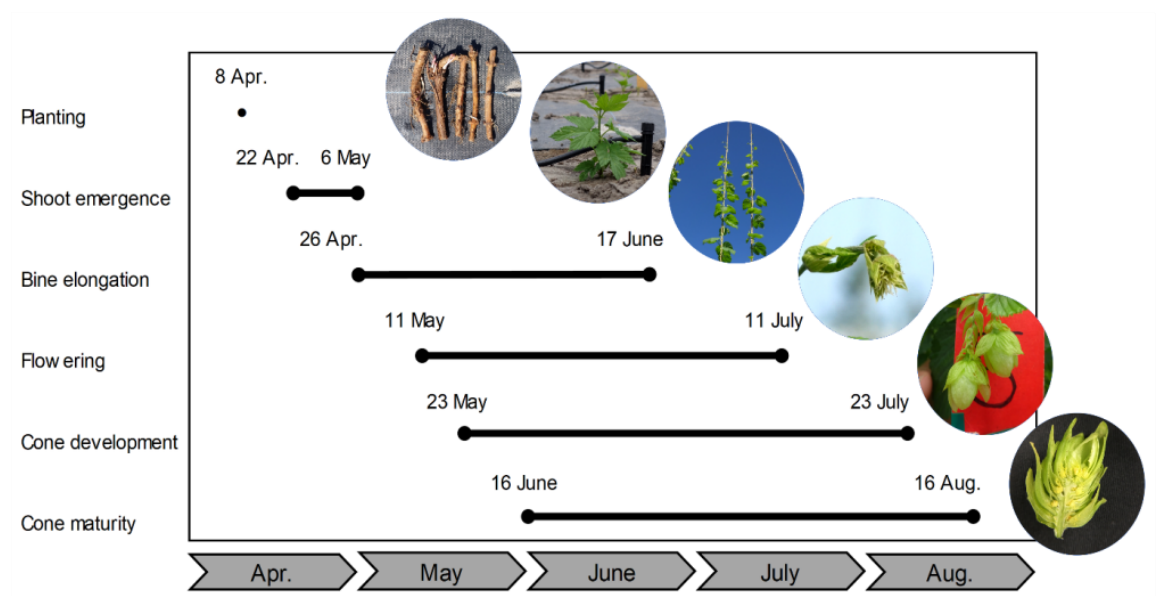

Fig 4. Phenology of 'Cascade' hops grown under subtropical climatic conditions (Balm, Florida, United States) during the 2016 season.

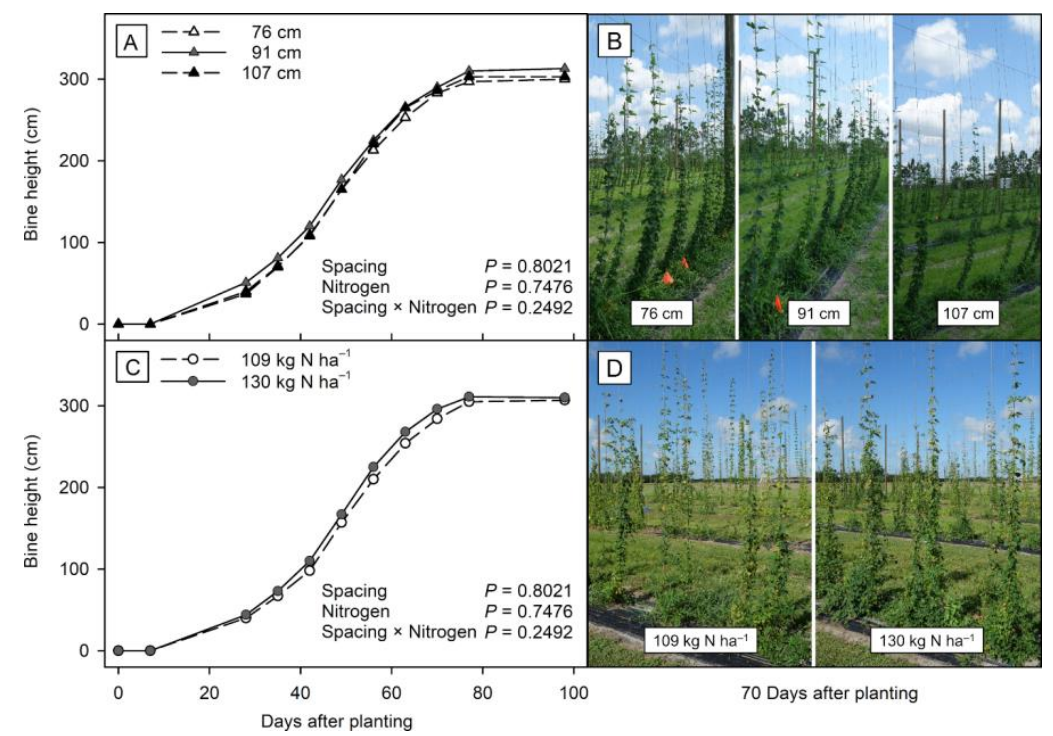

Fig 5. Vertical bine growth of 'Cascade' hops: (A) bine height growth $(n=8)$; $(B)$ photographs of hop plants grown with three different hill spacing; (C) bine height growth $(n=12)$; and $(D)$ photographs of hop plants grown with two different nitrogen $(N)$ rates. Because the hill spacing $\times \mathrm{N}$ rate interaction effect was non-significant, data were pooled for each hill spacing or $\mathrm{N}$ rate. 


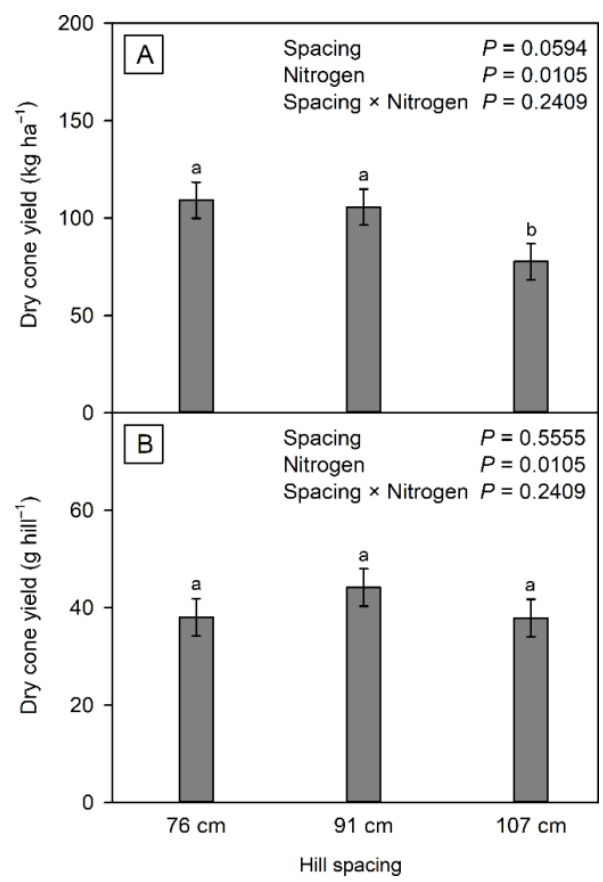

Fig 6. Dry cone yields of 'Cascade' hops at different hill spacing: (A) yield on a per area basis $\left(\mathrm{kg} \mathrm{ha}^{-1}\right)$ and (B) yield on a per hill basis $(\mathrm{g} \mathrm{hill}-1)$. Means $\pm \mathrm{SE}(\mathrm{n}=8)$ with the same letter are not significantly different (Tukey-Kramer test, $P<0.1)$. Because the hill spacing $\times \mathrm{N}$ rate interaction effect was non-significant, data were pooled for each hill spacing.

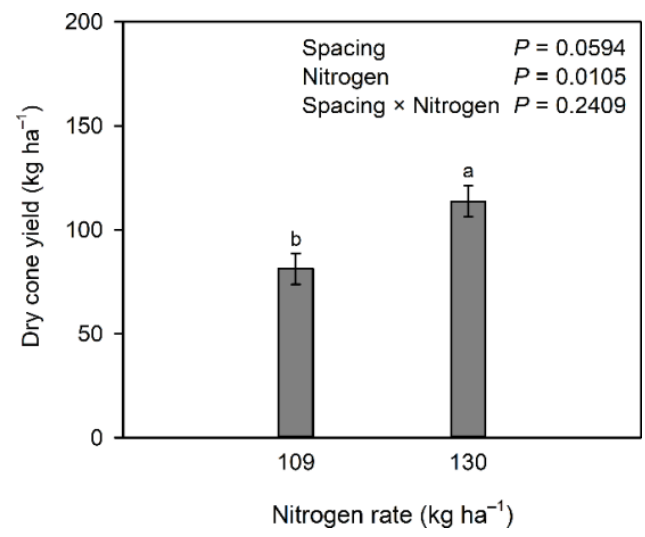

Fig 7. Dry cone yields of 'Cascade' hops grown at different $N$ rate applications. Means $\pm S E(n=12)$ with the same letter are not significantly different (Tukey-Kramer test, $P<0.1$ ). Because the hill spacing $\times \mathrm{N}$ rate interaction effect was non-significant, data were pooled for each $\mathrm{N}$ rate.

\section{Optimization of nitrogen fertilization for the first-season performance of 'Cascade' hops in Florida}

Hop production guides generally recommend applying $\mathrm{N}$ at $84 \mathrm{~kg} \mathrm{ha}^{-1}$ in the establishment year and at $100-225 \mathrm{~kg} \mathrm{ha}^{-1}$ in subsequent years for commercial hop production (Darby et al., 2015; Lizotte and Sirrine, 2020). The $\mathrm{N}$ rates used in this study are slightly higher than the recommended value for the establishment year, but they fit in the lower range of recommendation for established hop yards. This study showed improved growth and yield performances with increasing $\mathrm{N}$ rate from 109 to $130 \mathrm{~kg} \mathrm{ha}^{-1}$ (Figure 7). These results suggest that the optimum $\mathrm{N}$ rate for the establishment year could be higher in Florida than in traditional hop production areas. The relatively high $\mathrm{N}$ requirement in Florida may be due to the prolonged harvest window and the sandy soil that has poor water and nutrient retention capacity (Mylavarapu et al., 2019).

It is important to note that it takes multiple years to maximize the yield potential of hops. According to Sirrine et al. (2015), the conservative yield estimate for the first year is negligible, but $50 \%, 75 \%$, and $100 \%$ of production are expected in the second, third, and fourth year, respectively. For 'Cascade' grown in the Pacific Northwest in the US, these percentages correspond to 428,642 , and $856 \mathrm{~g}$ of dry cones per hill for the second, third and fourth year, respectively based on a yield of $1990 \mathrm{~kg} \mathrm{ha}^{-1}$, and a plant density of 2326 hills per hectare. Several studies have reported the first-year yield for 'Cascade': 200-300 g per hill in Colorado (a western US state), $35 \mathrm{~g}$ per hill in North Carolina (a southeastern US), and $470 \mathrm{~g}$ per hill in Italy (Austin, 2012; Bauerle, 2019; Ruggeri et al., 2018) (Original values were published with non-metric units or yield expressed as fresh weight, and were translated to dry cones in grams per hill for comparison purposes). In this study, 'Cascade' yields ranged 30-100 g of dry cones per hill in the first year, which are in the lower yield range based on the studies described above. The relatively low performance of hops in our study appears to be associated with the environmental conditions, most likely inadequate day length inducing premature flowering. 
Interestingly, increasing $\mathrm{N}$ rate did not promote vertical bine growth but increased yield by $27 \%$ (Figures $4 \mathrm{D}$ and 7 ). It appears that the vertical bine growth is strongly determined by the timing of flowering, and the optimization of $\mathrm{N}$ fertilization cannot override the flowering signal. Yield increase with increasing $\mathrm{N}$ rate was due mostly to the development of more bines or more laterals (data not collected), producing more nodes to develop flowers. Finally, the fact that yield was positively correlated with main bine number and lateral shoot number suggests that these growth traits should be considered to select high yielding cultivars or to evaluate the $\mathrm{N}$ response curve.

\section{Materials and methods}

\section{Soil and climatic conditions}

Field experiments were conducted in west-central Florida, US $\left(27.76^{\circ} \mathrm{N}, 82.23^{\circ} \mathrm{W}\right.$, altitude $\left.40 \mathrm{~m}\right)$, and it has a subtropical climate with hot and humid summers and mild winters (Figure 1). The mean annual precipitation in 2016 was $1392 \mathrm{~mm}$, with $68 \%$ of rainfalls occurring between May and August. The daily temperatures ranged from 22.6 to $33.9{ }^{\circ} \mathrm{C}$ during the summer (from June to September) and from 9.9 to $26.2{ }^{\circ} \mathrm{C}$ during the winter (from November to February). The relative humidity in 2016 averaged $80 \%$, and the wind speed was $10.5 \pm 3.56 \mathrm{kph}$ (FAWN, 2020). The soil at this experiment site is sandy soil classified as a Myakka fine sand siliceous hyperthermic Aeric Alaquods (USDA-NRCS, 2013), with cation exchange capacity of $6.9 \pm 1.5 \mathrm{meq} / 100 \mathrm{~g}$, soil $\mathrm{pH}$ of $6.5 \pm 0.3$ and $2 \%$ organic matter, according to the soil test performed by a commercial analytical laboratory (Waypoint Analytical, Mulberry, Florida).

\section{Crop management}

Plants were established from rhizomes and grown on a 6-m high straight trellis with one cable per row. The hop yard configuration and trellis design were built according to Agehara et al. (2020). The distance between the ground and the trellis cable was $5.8 \mathrm{~m}$. Two coconut coir twines were installed on each hill. The hop plants were watered and fertilized using an automated drip irrigation system. Other crop management practices, including bine training, manual weeding, and pest control, were performed as needed. No pruning was performed.

\section{Evaluation of hop cultivars}

In the first experiment, we evaluated 13 cultivars: seven American cultivars ('CTZ', 'Nugget', 'Crystal', 'Chinook', 'Cascade', 'Centennial' and 'Willamette'), five European cultivars ('Magnum', 'Tettnagger', 'Perle', 'Fuggle' and 'Saaz'), and one Japanese cultivar ('Sorachi Ace') (Table 1). The experiment followed a randomized complete block design with three blocks (replicates). Each experimental unit (field plot) consisted of four hills spaced $91 \mathrm{~cm}$ apart. Two rhizomes per hill were planted in mid-April 2016. Rizhomes were purchased from two commercial sources [Freshhops (Philomath, Oregon, US) and Hopsteiner (Yakima, Washington, US)] in late March or early April 2016. All plants were fertilized at $130 \mathrm{~N}-23 \mathrm{P}-173 \mathrm{~K} \mathrm{~kg} \mathrm{ha}^{-1}$ using urea and ammonium nitrate (UAN) and a $0 \mathrm{~N}-2 \mathrm{P}-8 \mathrm{~K}$ liquid fertilizer (Chemical Dynamics, Plant City, Florida, US). Fertigation was performed weekly throughout the season.

The maximum vertical bine height was measured in the field on 12 July, 88 days after planting (DAP). Number of bines per hill and number of laterals per hill were recorded on 27 June (73 DAP) and 12 July (88 DAP), respectively. Mature cones were hand-harvested weekly between 3 June and 29 Aug. 2016 (49-136 DAP). Harvested fresh cones were dried at 55 ${ }^{\circ} \mathrm{C}$ until they reached $10 \%$ of moisture.

\section{'Cascade' phenology and the effect of in-row hill spacing} and nitrogen rate applications in 'Cascade'

In the second experiment, treatments consisted of 3 levels of in-row hill spacing $(76,91$, or $107 \mathrm{~cm})$ and two nitrogen (N) application rates (109 and $130 \mathrm{~kg} \mathrm{ha}^{-1}$ ) in a factorial combination. The experiment followed a split-plot design with in-row hill spacing as the main plot factor and $\mathrm{N}$ application rate as the sub-plot factor. Treatments were replicated four times. Each experiment unit (field plot) consisted of 4 to 6 hills, depending on the in-row spacing. Fertigation of $\mathrm{N}$ at two different rates was performed using UAN. All plants were fertilized at $23 \mathrm{P}-173 \mathrm{~K} \mathrm{~kg} \mathrm{ha}^{-1}$ using a $0 \mathrm{~N}-2 \mathrm{P}-8 \mathrm{~K}$ liquid fertilizer. Fertigation was performed weekly throughout the season.

Plant development of 'Cascade' was recorded on a weekly basis or when visual changes were noted, from the planting date (8 Apr. 2016) to the last day of harvest (16 Aug. 2016). The developmental stages of 'Cascade' were described as a modified version of the $\mathrm{BBCH}$-scale for hops development (Rossbauer et al., 1995). The maximum bine height was measured on each of the 120 hop hills on a weekly basis from 8 Apr. to 15 July (0-98 DAP). The maximum bine height was measured using the image analysis procedure described by Agehara (2020). The number of bines per hill was recorded on 26 July (109 DAP). Mature cones were handharvested 10 times between 16 June and 16 Aug. 2016 (69130 DAP).

\section{Statistical analysis}

Statistical analysis was performed with SAS software (version 9.4, SAS Institute, NC, US) and Sigmaplot (version 14.0, Systat Software Inc., CA, US). For both experiments, data were subjected to analysis of variance, and mean differences were compared using the Tukey HSD test. $P$ values less than 0.05 or 0.10 were considered statistically significant. In the cultivar experiment, a linear correlation between yield and different growth traits (bine height, bine number, and lateral shoot number) was tested. The correlation was considered nonsignificant when the slope was not significantly different from zero $(P>0.05)$.

\section{Conclusion}

To the best of our knowledge, this is the first report describing the phenology of hops in a subtropical climate. Reproductive phenology was characterized by premature and prolonged flowering resulting in multiple harvests over 61 days from mid-June to mid-August. Although this altered phenology prevents once-over harvest, it may provide unique opportunities for subtropical hop production by enabling the off-season supply of fresh hops for an extended period. American cultivars with traditionally high yielding capacity, especially 'Cascade', 'CTZ', and 'Nugget', appear to adapt to subtropical climatic conditions better than Europeans and Japanese cultivars. Plant growth traits related to flower formation, such as main bine number and lateral branching, are critical to achieving high cone yields. Yield increases by $38 \%$ to $41 \%$ by reducing hill spacing and increasing $\mathrm{N}$ rate suggest that yield could be further increased by optimizing crop management practices. Our findings provide a benchmark to develop strategies aimed for successful subtropical hop production. 


\section{Acknowledgments}

This study was supported in part by the Florida Specialty Crop Block Grant Program 16SCBGPFL0041. Additional support was provided by Redner Family Foundation, Bailey Family Foundation, 3 Daughters Brewing, Coppertail Brewing, Cigar City Brewing, and Hopsteiner. We thank Chris DelCastillo, Joyce Jones, Gail Bowman, and Keri Druffel at the Gulf Coast Research and Education Center for their technical assistance.

\section{References}

Agehara S (2020) Simple imaging techniques for plant growth assessment. University of Florida IFAS Extension. HS1353.

Agehara S, Acosta-Rangel A, Deng Z, Rechcigl J, Bollin S (2020) Hop yard establishment and trellis construction in Florida. University of Florida IFAS Extension. HS1345.

Allen R (2018) Michigan grows to No. 1 in hops production outside Pacific Northwest. Detroit Free Press. Accessed May 21, 2020. https://www.freep.com/story/entertainment/2018/02/14 /michigan-hops-farms/314513002/.

Austin R (2012) NC Hops 2010-2012 Research project observations. North Carolina State University Extension. Accessed May 11, 2020. https://newcropsorganics.ces.ncsu.edu/specialtycrops/nc-hops/observations/\#sampling.

Bauerle WL (2019) Disentangling photoperiod from hop vernalization and dormancy for global production and speed breeding. Sci Rep. 9:16003.

Bergstrand K, Schüssler H (2013) Growth, development and photosynthesis of some horticultural plants as affected by different supplementary lighting technologies. Europ J Hort Sci. 78(3):1611-4426.

Boutain J (2014) On the origin of hops: genetic variability, phylogenetic relationships, and ecological plasticity of Humulus (Cannabaceae) PhD Thesis, University of Hawaii, Manoa, Hawaii.

Brewers Association (2020) National beer sales and production data. Accessed June 1, 2020. https://www.brewersassociation.org/statistics-anddata/national-beer-stats/.

Crain MN (2011) Factors controlling hop flowering and their potential for use in the brewing and pharmaceutical industries PhD Thesis, University of Northern lowa, US.

Darby H Callahan C, Rainville R (2015) Hops production in New England. University of Vermont Extension. Accessed April 6, 2020. http://www.uvm.edu/extension/cropsoil/hops.

De Keukeleire J, Ooms G, Heyerick A, Roldan-Ruiz I, Van Bockstaele E, De Keukeleire D (2003) Formation and accumulation of $\alpha$-acids, $\beta$-acids, desmethylxanthohumol, and xanthohumol during flowering of hops (Humulus lupulus L.). J Agric Food Chem. 51(15):4436-4441.

DeNoma J (2000) Hop genetic resources. US Department of Agriculture - Agricultural Research Service, National Clonal Germplasm Repository. Corvalis, OR. Accessed April 3, 2020. https://www.ars.usda.gov/pacific-west-

Ruggeri R, Loreti P, Rossini F (2018) Exploring the potential of hop as a dual-purpose crop in the Mediterranean environment: shoot and cone yield from nine commercial cultivars. Eur J Agron. 93:11-17. area/corvallis-or/national-clonal-germplasm-

repository/docs/ncgr-corvallis-humulus-

germplasm/\#introduction.

Del Moro S (2015) Basic hop physiology and stages of production. John I. Haas, Inc. Accessed March 25, 2019. Microsoft PowerPoint presentation. https://www.canr.msu.edu/uploads/236/71505/Basic_Ho p_Physiology.pdf.

Dodds K (2017) Hops. A guide for new growers. NSW Department of Primary Industries. Australian Government.

Florida Automated Weather Network (FAWN) (2020) University of Florida IFAS Extension. Accessed April 4, 2020. https://fawn.ifas.ufl.edu/.

Forward LR (2017) Hop establishment impacted by mulch type and nitrogen source PhD Thesis, North Dakota State University.

Hop Growers of America (2019) Overview of the hop industry. Accessed April 7, 2020. https://www.usahops.org/enthusiasts/.

Hopsteiner (2016) Hop selection and harvest. Accessed July 17, 2020. https://www.hopsteiner.com/hop-selectionharvest/.

International Hop Growers' Convention (IHGC) (2020) Economic Commission Summary Reports. Accessed May 5, 2020. https://www.usahops.org/img/blog_pdf/321.pdf.

Iskra AE, Lafontaine SR, Trippe KM, Massie ST, Phillip CL, Twomey MC, Shellhammer TH, Gent DH (2019) Influence of nitrogen fertility practices on hop cone Quality. J Am Soc Brew Chem. 77(3):199-209.

Jakse J, Satovic Z, Javornik B (2004) Microsatellite variability among wild and cultivated hops (Humulus lupulus L.). Genome. 47(5):889-99.

Kemme $L$ (2013) Selecting the right trellis design to grow great hops. Greatlake Hops. Accessed April 9, 2020. https://www.greatlakeshops.com/hops-blog/selectingthe-right-trellis-design-to-grow-great-hops.

Krebs C (2019) Hops: A viable alternative crop for the Central/Southern Plains? Crops and Soils. 52(4):4-6.

Kořen J (2007) Influence of plantation row spacing on quality and yield of hops. Plant Soil Environ. 53:276-282.

Lee $\mathrm{YH}$, Cho BO, Huh BL, Ho QS (1992) Effect of nitrogen application on the yield and quality of hop (Humulus lupulus L.). Korean J Soil Sci Fert. 25(1):38-43.

Lizotte E, Sirrine R (2020) Michigan hop management guide 2020. Michigan State University Extension.

McClellan J, McWhirt A (2019) 2019 Hops Production trial. University of Arkansas Cooperative Extension Service. Accessed April 13, 2020. https://www.uaex.edu/farmranch/crops-commercial-horticulture/horticulture/ar-fruitveg-nut-update-blog/posts/hopsproductiontrial.aspx.

Murakami A, Darby P, Javornik B, Pais M, Seigner E, Lutz A Svoboda P (2006) Molecular phylogeny of wild Hops, Humulus lupulus L. Heredity. 97:66-74.

Mylavarapu R, Harris W, Hochmuth G (2019) Agricultural soils in Florida. University of Florida IFAS Extension. SL441. Neve RA (1991) Hops, 1st edn. Chapman and Hall, England.

Rossbauer GL, Buhr H, Hack S, Hauptmann R, Klose U, Meier $\mathrm{R}$, Stauss E (1995) Phenological growth stages in hop (Humulus lupulus L.). Nachrichtenbl. Deut. Pflanzenschutzd 47:249-25.

Sirrine R (2015) Michigan fresh: Growing hops. Michigan State University Extension. E3210.

Sirrine R, Lizotte E, Brown D, O'Brien T, Leac A (2015) Estimated costs of producing hops in Michigan. E3236. 
Thomas GG, Schwabe WW (1969) Factors controlling flowering in the hop (Humulus lupulus L.). Ann Bot. 33(4):781-793.

US Department of Agriculture - Agricultural Research Service (USDA-ARS) (2007) Hop cultivar descriptors. Accessed October 25, 2019. https://www.ars.usda.gov/pacific-westarea/corvallis-or/forage-seed-and-cerealresearch/people/john-henning/cultindex/.

US Department of Agriculture - National Agricultural Statistics Service (USDA-NASS) (2019) National hop report.
Agricultural Statistics Board. Accessed April 1, 2020. https://www.nass.usda.gov/Statistics by State/Regional Office/Northwest/includes/Publications/Hops/National\% $\overline{2}$ Ohop_2019.pdf.

US Department of Agriculture - National Resources Conservation Service (USDA-NRCS) (2013) Official Series Description - MYAKKA Series. Accessed May 4, 2020. https://soilseries.sc.egov.usda.gov/OSD_Docs/M/MYAKKA .html. 